\title{
Comparative Study between Naloxone as an Additive to Lidocaine and Naloxone Infusion in Intravenous Regional Anaesthesia for Short Procedures of Upper Limb Surgeries
}

\author{
Ali Abdalla Ali Eissa, Alaa El-Din Mahmoud Sayed, \\ Mohammed Mohammed El-sayed Ameen Hegab* \\ Department of Anesthesiology and Intensive Care, \\ Faculty of Medicine, Al-Azhar University \\ *Corresponding author: Mohammed Mohammed El-sayed Ameen Hegab, Mobile: 01001026864; Email: \\ dr.hegab1985@gmail.com
}

\begin{abstract}
Background: intravenous regional anesthesia (IVRA) was first described by August Bier in 1908. IVRA is an anesthetic technique for surgical procedures on the body's extremities where a local anesthetic is injected intravenously. The local anesthetic diffuses from the peripheral vascular bed to nonvascular tissue such as axons and nerve endings.
\end{abstract}

Objective: The aim of the present study was to compare the effect of adding ultra-low dose of naloxone to lidocaine for IVRA and the effect of using intravenous naloxone infusion with IVRA for elective short procedures in the upper limb.

Patients and Methods: This is Prospective; randomized, controlled, multicenter, double blind study that done in Alazhar University hospitals. Each group contains 30 patients. The lidocaine in the study is $2 \% 3 \mathrm{mg} / \mathrm{kg}$ in all groups. In all groups $0.9 \% \mathrm{NaCl}$ is added to make up a total volume of $30 \mathrm{ml}$.

Results: The result of our study showed that local intravenous adjuvant naloxone (100 or 50ng) with lidocaine $1 \%$ shortens the onset of blocks and prolongs the recovery from anesthesia. Moreover, it reduces the amount of opioids consumption and intraoperative pain score in patient undergoing short upper limb surgeries.

Conclusion: Naloxone IV infusion not improves the analgesic effect of intravenous anesthesia or prolongs the recovery from anesthesia. Regarding safety, adjuvant naloxone appears to be safe with no recorded side effects.

Keywords: Lidocaine, naloxone, intravenous regional anesthesia

\section{INTRODUCTION}

Intravenous regional anesthesia (IVRA) is simple, reliable, and cost-effective, with a success rate varying between $94 \%$ and $98 \%{ }^{(1)}$.

IVRA is a favorable choice among anesthesiologists for extremity operations lasting around one hour. However there are some concerns associated with IVRA such as tourniquet pain, inadequate muscle relaxation, insufficient postoperative analgesia and local anesthetic toxicity ${ }^{(2)}$.

Naloxone has proved to have paradoxical effects as it antagonizes the opioid analgesia if given in high doses (microgram range) and produces anti-nociceptive effect if given in ultra-low doses (nanogram range) ${ }^{(3)}$.

Different mechanisms have explained the effect of ultra-low dose naloxone including selective inhibition of the impulses from excitatory opioid receptors and release of enkephalin ${ }^{(4)}$.

\section{AIM OF THE WORK}

The aim of the present study is to compare the effect of adding ultra-low dose of naloxone to lidocaine for IVRA with lidocaine IVRA combined with ultra - low dose and the effect of using intravenous naloxone infusion with IVRA for elective short surgical procedures in the upper limb (hand and forarm).

\section{PATIENTS AND METHODS}

Patients: This is Prospective, randomized, controlled, multicenter, double blind study, After obtaining approval from the Ethical Committee, patients of ASA grade I or II age between 20-60 years who were scheduled for forearm and hand surgery lasting for less than 60 minutes are included in this study.This study conducted in Al-Azhar University Hospitals on Hundred and fifty 
patients of both sex after obtaining written informed consent from the patient.hundred and fifty consecutive patients were divided randomly into 5 groups. Using a computerized program (SPSS). Sealed envelopes were numbered according to the randomization tables. Packing, sealing and numbering of the envelops prepared by a medical personnel (Under the supervision of doctors from the Department of Anesthesiology). Each group contains 30 patients. The lidocaine in the study is $2 \% 3 \mathrm{mg} / \mathrm{kg}$ in all groups. In all groups $0.9 \%$ $\mathrm{NaCl}$ is added to make up a total volume of 30 $\mathrm{ml}$.

Statistical analysis: Sample size justification: Sample size was calculated using EpiInfo ${ }^{\circledR}$ version 6.0, setting the type-1 error $(\alpha)$ at 0.05 and the power $(1-\beta)$ at 0.80 .

Study groups: Group 1: (Regional 100) $(\mathbf{n}=30)$ : Was undergone intravenous regional anesthesia using lidocaine and naloxone (3 $\mathrm{mg} / \mathrm{kg}$ of $2 \%$ lidocaine and naloxone $100 \mathrm{ng}(1$ $\mathrm{ml}$ ) diluted with normal saline to $30 \mathrm{ml}$ ). Group 11: (Regional 50) $(\mathbf{n}=\mathbf{3 0})$ : Was undergo intravenous regional anesthesia using lidocaine and naloxone $(3 \mathrm{mg} / \mathrm{kg}$ of $2 \%$ lidocaine and naloxone $50 \mathrm{ng}(1 \mathrm{ml})$ diluted with normal saline to $30 \mathrm{ml}$ ).

Group 111: (Intravenous $0.25 \mathrm{ug} / \mathrm{kg} / \mathrm{hr}$ ) $(\mathbf{n}=30)$ : Was undergone intravenous regional anesthesia using lidocaine and intravenous naloxone infusion $(3 \mathrm{mg} / \mathrm{kg}$ of $2 \%$ lidocaine diluted with normal saline to $30 \mathrm{ml}$ will be given to the operating hand) and in the other hand naloxone infusion at a rate of $(0.25$ $\mathrm{ug} / \mathrm{kg} / \mathrm{h}$ ).

Group 1V: (Intravenous 0.15ug/kg/hr) $(\mathbf{n}=30)$ : Was undergone intravenous regional anesthesia using lidocaine and intravenous naloxone infusion $(3 \mathrm{mg} / \mathrm{kg}$ of $2 \%$ lidocaine diluted with normal saline to $30 \mathrm{ml}$ will be given to the operating hand) and in the other hand naloxone infusion at a rate of $(0.15$ $\mathrm{ug} / \mathrm{kg} / \mathrm{h})$.

Group V: (Control group) $(\mathbf{n}=\mathbf{3 0})$ : Control group: was undergone intravenous regional anesthesia using lidocaine $(3 \mathrm{mg} / \mathrm{kg}$ of $2 \%$ lidocaine diluted with normal saline to $30 \mathrm{ml}$ will be given to the operating hand) and in the other hand intravenous normal saline infusion.

Inclusion criteria: Age: 20-60 years old. American Society of Anesthesiologist (ASA) physical status I, II. Operation: forearm or hand surgeries such as distal radius fracture (DR), plate ulna (PU) for ulnar bone fracture, metacarpal bone fracture (MCF), trigger finger (TF), simple ganglion resection (SG) and carpal tunnel syndrome(CTS).

Exclusion criteria: Patients who have history of allergy to one of the study medications. History of chronic pain or regular medication with analgesics. History of opioid dependence, drug or alcohol abuse. Psychiatric disorder and neurological diseases. ASA class III and IV patients. Patients with peripheral arterial disease, or sickle cell disease. Patients with open wounds and infection of the operative limb. Uncooperative patients. Lengthy operations. Patient's refusal. Diabetic, hypertensive and cardiac patient.

Preoperative:

Preoperative assessment: Routine preoperative assessment to fulfill patients criteria for the study by full history taking, physical examination including chest and heart examination.Study protocol was explained to the patients taking their consent. Explanation of Visual Analog Scale (VAS) scoring system for all patients. Premedication for all groups consisted of IV midazolam $0.05 \mathrm{mg} / \mathrm{kg} 10 \mathrm{~min}$ before the block. Routine investigations: CBC, ALT,AST, serum albumin and bilirubin level, serum urea and creatinine level and coagulation profile.

\section{Methods:}

Double pneumatic tourniquet, the pressure gauge should be checked for leaks before the procedure.

Esmarch bandage for exsanguination.

Two IV catheters, size 20G and 22G,Infusion set, $5 \mathrm{ml}$ and $20 \mathrm{ml}$ syringes.

Drugs: Lidocaine (Lidocaine injection $2 \%$, 20ml preservative free, ALDebikypharma, Egypt), Naloxone (Naloxone hydrochloride anhydrous injection, $0.4 \mathrm{mg} / 1 \mathrm{ml}$ preservative free, MYLAN).

Equipment and drugs for general anesthesia and resuscitation: Oxygen supply, airway, laryngoscope with different size blades, endotracheal tubes of different sizes, suction apparatus, thiopental, succinylcholine, atropine, epinephrine and DC shock.

After application of monitors (ECG, SPO2, NIBP) to the patient lying in supine position; a cannula, $20 \mathrm{G}$ size, was placed in the non-operative hand for crystalloid infusion and emergency drugs. Another cannula 22G 
size, was inserted in a dorsal vein of the operative hand.

A double pneumatic tourniquet is then placed around the upper arm of the operative limb, over a pad of cotton. The arm is elevated for 2 minutes then exsanguinated with an Esmarch bandage. In case of a painful limb, where exsanguination of the limb could not be carried out, limb elevation was done with axillary artery compression for 5 minutes.

The proximal cuff will be inflated to $100 \mathrm{~mm} \mathrm{Hg}$ above the patient's systolic pressure. Circulatory isolation of the arm was verified by inspection, absence of radial pulse and loss of pulse oximetry tracing in the ipsilateral index finger. Then $30 \mathrm{ml}$ of lidocaine $3 \mathrm{mg} / \mathrm{kg}$ in control group,lidocaine with naloxone $100 \mathrm{ng}$ in naloxone group 1, lidocaine with naloxone $50 \mathrm{ng}$ in naloxone group 2, lidocaine and in the other hand naloxone infusion at a rate of $(0.25 \mathrm{ug} / \mathrm{kg} / \mathrm{h})$. in naloxone I group1and lidocaine and in the other hand naloxone infusion at a rate of $(0.15$ $\mathrm{ug} / \mathrm{kg} / \mathrm{h}$ ). In naloxone I group2 was injected slowly within 60 seconds (Figure 11A,B,C).

When anesthesia was established confirmed by complete sensory and motor block, the distal cuff of the tourniquet was inflated to $250 \mathrm{mmHg}$ then the proximal one was deflated. The least time before tourniquet release was 30 minutes and the maximum time could be allowed was 90 minutes.

\section{RESULTS}

Table (1): The hemodynamics: There was no significant difference between different follow up in terms of HR, MAP and SpO2.

\begin{tabular}{|c|c|c|c|c|c|c|c|c|c|c|}
\hline Variables & Group & Baseline & $\begin{array}{c}5 \\
\min \end{array}$ & $\begin{array}{c}10 \\
\min \end{array}$ & $\begin{array}{c}15 \\
\min \end{array}$ & $\begin{array}{c}20 \\
\min \end{array}$ & $\begin{array}{c}30 \\
\text { min }\end{array}$ & $40 \mathrm{~min}$ & End & $\begin{array}{c}\text { P- } \\
\text { value }\end{array}$ \\
\hline \multirow{5}{*}{$\begin{array}{c}\text { HR in beats/min, Mean } \\
(\mathrm{SD})\end{array}$} & $\begin{array}{l}\mathrm{NL} \\
100\end{array}$ & $\begin{array}{l}80.2 \\
(3.4)\end{array}$ & $\begin{array}{l}80.5 \\
(3.1)\end{array}$ & $\begin{array}{l}80.8 \\
(3.5)\end{array}$ & $\begin{array}{l}80.6 \\
(3.4)\end{array}$ & $\begin{array}{l}80.4 \\
(3.4)\end{array}$ & $\begin{array}{l}80.6 \\
(3.5)\end{array}$ & $80.5(3.3)$ & $\begin{array}{l}81.3 \\
(3.5)\end{array}$ & 0.052 \\
\hline & NL 50 & $\begin{array}{l}80.6 \\
(3.7)\end{array}$ & $\begin{array}{c}81 \\
(3.2)\end{array}$ & $\begin{array}{l}80.8 \\
(3.5)\end{array}$ & $\begin{array}{l}80.7 \\
(3.5)\end{array}$ & $\begin{array}{l}80.4 \\
(3.4)\end{array}$ & $\begin{array}{l}80.6 \\
(3.7)\end{array}$ & $80.8(3.9)$ & $\begin{array}{l}80.6 \\
(3.8)\end{array}$ & 0.61 \\
\hline & $\begin{array}{l}\text { N IV } \\
0.25\end{array}$ & $\begin{array}{l}80.8 \\
(3.3)\end{array}$ & $\begin{array}{c}80.7 \\
(3)\end{array}$ & $\begin{array}{l}80.5 \\
(3.2)\end{array}$ & $\begin{array}{l}80.6 \\
(3.2)\end{array}$ & $\begin{array}{l}80.7 \\
(3.2)\end{array}$ & $\begin{array}{l}80.7 \\
(3.4)\end{array}$ & $80.5(3.5)$ & $\begin{array}{l}80.7 \\
(3.1)\end{array}$ & 0.89 \\
\hline & $\begin{array}{l}\text { N IV } \\
0.15\end{array}$ & $\begin{array}{l}80.7 \\
(2.9)\end{array}$ & $\begin{array}{c}80.3 \\
(2)\end{array}$ & $\begin{array}{l}80.5 \\
(2.7)\end{array}$ & $\begin{array}{l}80.4 \\
(1.7)\end{array}$ & $\begin{array}{c}80 \\
(1.8) \\
\end{array}$ & $\begin{array}{l}80.3 \\
(1.9)\end{array}$ & $80.2(2.3)$ & $\begin{array}{l}80.4 \\
(2.4)\end{array}$ & 0.92 \\
\hline & $\mathrm{L}$ & 81 (3.9) & $\begin{array}{l}80.5 \\
(3.2)\end{array}$ & $\begin{array}{c}81 \\
(3.4)\end{array}$ & $\begin{array}{c}81 \\
(3.7)\end{array}$ & $\begin{array}{l}81.1 \\
(3.3)\end{array}$ & $\begin{array}{l}80.8 \\
(3.2)\end{array}$ & $80.8 \quad(2.9)$ & $\begin{array}{l}80.9 \\
(3.3)\end{array}$ & 0.76 \\
\hline \multirow{5}{*}{ MAP in $\underset{(\mathrm{SD})}{\mathbf{m m H g}, \text { Mean }}$} & $\begin{array}{l}\mathrm{NL} \\
100\end{array}$ & $\begin{array}{l}96.7 \\
(1.4)\end{array}$ & $\begin{array}{l}96.3 \\
(1.4)\end{array}$ & $\begin{array}{l}96.2 \\
(1.5)\end{array}$ & $\begin{array}{l}96.2 \\
(1.4)\end{array}$ & $\begin{array}{l}96.2 \\
(1.6)\end{array}$ & $\begin{array}{l}96.3 \\
(1.4)\end{array}$ & $96.4(1.4)$ & $\begin{array}{l}96.3 \\
(1.6)\end{array}$ & 0.09 \\
\hline & NL 50 & $\begin{array}{l}96.6 \\
(1.4) \\
\end{array}$ & $\begin{array}{c}96 \\
(1.3)\end{array}$ & $\begin{array}{l}96.8 \\
(1.4) \\
\end{array}$ & $\begin{array}{l}96.6 \\
(1.2) \\
\end{array}$ & $\begin{array}{l}96.8 \\
(1.5)\end{array}$ & $\begin{array}{l}96.8 \\
(1.4) \\
\end{array}$ & $95.9(1.4)$ & $\begin{array}{c}96 \\
(1.5)\end{array}$ & 0.14 \\
\hline & $\begin{array}{l}\text { N IV } \\
0.25\end{array}$ & $\begin{array}{l}97.3 \\
(1.6)\end{array}$ & $\begin{array}{l}97.4 \\
(1.3)\end{array}$ & $\begin{array}{l}97.1 \\
(1.3)\end{array}$ & $\begin{array}{l}96.9 \\
(1.4)\end{array}$ & $\begin{array}{l}96.8 \\
(1.5)\end{array}$ & $\begin{array}{l}96.9 \\
(1.5)\end{array}$ & $97(1.5)$ & $\begin{array}{l}97.2 \\
(1.4)\end{array}$ & 0.63 \\
\hline & $\begin{array}{l}\text { N IV } \\
0.15\end{array}$ & $\begin{array}{l}97.2 \\
(1.4)\end{array}$ & $\begin{array}{l}97.6 \\
(1.3)\end{array}$ & $\begin{array}{l}96.7 \\
(1.5)\end{array}$ & $\begin{array}{l}97.6 \\
(1.4)\end{array}$ & $\begin{array}{l}97.4 \\
(1.2)\end{array}$ & $\begin{array}{l}97.8 \\
(1.3)\end{array}$ & $97.8(1.4)$ & $\begin{array}{l}97.3 \\
(1.4)\end{array}$ & 0.34 \\
\hline & $\mathrm{L}$ & $\begin{array}{l}96.6 \\
(1.6)\end{array}$ & $\begin{array}{l}96.5 \\
(1.8)\end{array}$ & $\begin{array}{l}96.2 \\
(1.6)\end{array}$ & $\begin{array}{l}96.4 \\
(1.8)\end{array}$ & $\begin{array}{l}96.4 \\
(1.5)\end{array}$ & $\begin{array}{l}96.3 \\
(1.6)\end{array}$ & $96.4 \quad$ (1.9) & $\begin{array}{l}96.4 \\
(1.6)\end{array}$ & 0.44 \\
\hline \multirow[t]{5}{*}{ SpO2, Mean (SD) } & $\begin{array}{l}\text { NL } \\
100 \\
\end{array}$ & $\begin{array}{l}97.9 \\
(0.6) \\
\end{array}$ & $\begin{array}{l}98.2 \\
(0.7) \\
\end{array}$ & $\begin{array}{l}98.3 \\
(0.6) \\
\end{array}$ & $\begin{array}{l}98.1 \\
(0.7) \\
\end{array}$ & $\begin{array}{l}98.3 \\
(0.7) \\
\end{array}$ & $\begin{array}{l}98.2 \\
(0.6)\end{array}$ & $98.5(0.6)$ & $\begin{array}{l}98.4 \\
(0.5)\end{array}$ & 0.12 \\
\hline & NL 50 & $\begin{array}{l}98.8 \\
(0.6)\end{array}$ & $\begin{array}{l}98.3 \\
(0.7)\end{array}$ & $\begin{array}{l}98.3 \\
(0.7)\end{array}$ & $\begin{array}{l}98.2 \\
(0.6)\end{array}$ & $\begin{array}{l}98.3 \\
(0.5)\end{array}$ & $\begin{array}{l}98.2 \\
(0.6)\end{array}$ & $98.4(0.5)$ & $\begin{array}{l}98.4 \\
(0.5)\end{array}$ & 0.23 \\
\hline & $\begin{array}{l}\text { N IV } \\
0.25\end{array}$ & $\begin{array}{l}98.8 \\
(0.7)\end{array}$ & $\begin{array}{l}98.6 \\
(0.5)\end{array}$ & $\begin{array}{l}98.6 \\
(0.5)\end{array}$ & $\begin{array}{l}98.2 \\
(0.6)\end{array}$ & $\begin{array}{l}98.4 \\
(0.6)\end{array}$ & $\begin{array}{l}98.2 \\
(0.5)\end{array}$ & $98.4(0.6)$ & $\begin{array}{l}98.4 \\
(0.5)\end{array}$ & 0.25 \\
\hline & $\begin{array}{l}\text { N IV } \\
0.15 \\
\end{array}$ & $\begin{array}{l}97.9 \\
(0.7)\end{array}$ & $\begin{array}{l}98.3 \\
(0.7)\end{array}$ & $\begin{array}{l}98.2 \\
(0.7)\end{array}$ & $\begin{array}{l}98.1 \\
(0.7)\end{array}$ & $\begin{array}{c}98 \\
(0.7) \\
\end{array}$ & $\begin{array}{l}97.9 \\
(0.7)\end{array}$ & $98(0.8)$ & $\begin{array}{l}98.2 \\
(0.7)\end{array}$ & 0.292 \\
\hline & $\mathrm{L}$ & $\begin{array}{l}97.7 \\
(0.6)\end{array}$ & $\begin{array}{l}98.4 \\
(0.7)\end{array}$ & $\begin{array}{l}98.2 \\
(0.8)\end{array}$ & $\begin{array}{l}98.3 \\
(0.7)\end{array}$ & $\begin{array}{c}98 \\
(0.6)\end{array}$ & $\begin{array}{l}98.3 \\
(0.7)\end{array}$ & $98.5(0.7)$ & $\begin{array}{l}97.8 \\
(0.7)\end{array}$ & 0.52 \\
\hline
\end{tabular}


Table 2: The change in Intraoperative VAS score:

Significant difference was detected between different follow up in terms of VAS score, $\mathrm{p}<0.001$.

\begin{tabular}{|c|c|c|c|c|c|c|c|c|c|}
\hline Group & & AS score & $5 \mathrm{~min}$ & $10 \mathrm{~min}$ & $15 \mathrm{~min}$ & $30 \mathrm{~min}$ & $45 \mathrm{~min}$ & End & P-value \\
\hline \multirow{2}{*}{ NL 100} & 1. & Mean (SD) & $1.5(0.6)$ & $1.2(0.7)$ & $2.2(0.4)$ & $2(1)$ & $1(0.7)$ & $1.1(0.7)$ & 0.001 \\
\hline & 2. & Median (IQR) & $2(1-2)$ & $1(1-2)$ & $2(1-3)$ & $1(1-3)$ & $1(1-1)$ & $(1-2)$ & \\
\hline \multirow{2}{*}{ NL 50} & 1. & Mean (SD) & $1.3(0.8)$ & $1.5(0.6)$ & $2.1(0.9)$ & $2.1(0.5)$ & $1.1(0.8)$ & $1(0.7)$ & 0.001 \\
\hline & 2. & Median (IQR) & $2(1-2)$ & $2(1-2)$ & $2(1-2)$ & $2(1-3)$ & $1(1-2)$ & $1(1-2)$ & \\
\hline \multirow{2}{*}{ N IV 0.25} & 1. & Mean (SD) & $2.3(0.6)$ & $2.3(0.6)$ & $2.1(0.7)$ & $2.2(1)$ & $2.6(1)$ & $2.3(0.6)$ & $<0.001$ \\
\hline & 2. & Median (IQR) & $2(2-3)$ & $2(2-3)$ & $2(2-3)$ & $3(2-3)$ & $2(1-3)$ & $2(2-3)$ & \\
\hline \multirow{2}{*}{ N IV 0.15} & 1. & Mean (SD) & $1.4(0.6)$ & $1.4(0.6)$ & $2.4(1.1)$ & $2.4(1.1)$ & $2.2(0.9)$ & $2.5(0.5)$ & $<0.001$ \\
\hline & 2. & Median (IQR) & $1.5(1-2)$ & $1(1-2)$ & $2(1-3)$ & $2.5(1-3)$ & $2.5(2-3)$ & $2(2-3)$ & \\
\hline \multirow{2}{*}{$\mathrm{L}$} & 1. & Mean (SD) & $1.3(0.7)$ & $1.7(0.5)$ & $2(0.9)$ & $2.5(1.1)$ & $2.9(0.7)$ & $2.6(0.5)$ & $<0.001$ \\
\hline & 2. & Median (IQR) & $1(1-2)$ & $2(2-3)$ & $2(2-3)$ & $2(2-3)$ & $3(2-3)$ & $3(2-3)$ & \\
\hline
\end{tabular}

Table 3: The change in postoperative VAS score:

The mean postoperative VAS score in the NL 100 group changed significantlyat the endof follow up, $\mathrm{p}=0.001$.Similarly, the mean postoperative VAS score in the NL 50, N IV 0.25, N IV 0.15, and L groupsshowed a significant difference different follow up score, $\mathrm{p}=0.001$.

\begin{tabular}{|c|c|c|c|c|c|c|c|c|}
\hline Group & VAS score & $30 \mathrm{~min}$ & $60 \mathrm{~min}$ & $120 \mathrm{~min}$ & $180 \mathrm{~min}$ & $240 \mathrm{~min}$ & $360 \mathrm{~min}$ & P-value \\
\hline \multirow{2}{*}{ NL 100} & 1. Mean (SD) & $2.2(0.41)$ & $3.6(0.8)$ & $2.2(0.4)$ & $2.3(0.5)$ & $2.2(0.4)$ & $2.2(0.5)$ & 0.001 \\
\hline & 2. Median (IQR) & $2(1-3)$ & $3(2-4)$ & $2(2-3)$ & $2(2-3)$ & $2(1-3)$ & $2(1-3)$ & \\
\hline \multirow{2}{*}{ NL 50} & 1. Mean (SD) & $1.6(0.5)$ & $2.9(1)$ & $2.3(0.9)$ & $1.6(0.5)$ & $1.6(0.5)$ & $1.5(0.5)$ & 0.001 \\
\hline & 2. Median (IQR) & $2(1-2)$ & $3(2-4)$ & $2(1-3)$ & $2(1-2)$ & $1(1-2)$ & $1(1-2)$ & \\
\hline \multirow{2}{*}{ N IV 0.25} & 1. Mean (SD) & $3.9(0.9)$ & $3.7(0.8)$ & $2.7(0.5)$ & $2.8(0.5)$ & $4.2(0.7)$ & $2.8(0.4)$ & $<0.001$ \\
\hline & 2. Median (IQR) & $4(3-5)$ & $4(4-5)$ & $2(2-3)$ & $3(2-3)$ & $4(4-5)$ & $2(2-3)$ & \\
\hline \multirow{2}{*}{ N IV 0.15} & 1. Mean (SD) & $2.4(0.5)$ & $3.8(0.8)$ & $2.7(0.7)$ & $2.4(0.5)$ & $3.1(0.8)$ & $3.1(0.7)$ & $<0.001$ \\
\hline & 2. $\quad$ Median (IQR) & $1.5(1-2)$ & $4(3-5)$ & $2(1-3)$ & $2(2-3)$ & $3(3-4)$ & $3(3-4)$ & \\
\hline \multirow{2}{*}{$\mathrm{L}$} & 1. Mean (SD) & $3.7(1)$ & $3.8(1.1)$ & $2.5(0.5)$ & $2.5(0.5)$ & $4.1(0.7)$ & $2.5(0.5)$ & $<0.001$ \\
\hline & 3. Median (IQR) & $3(3-4)$ & $4(2-5)$ & $2(2-3)$ & $2(2-3)$ & $4(3-5)$ & $3(2-3)$ & \\
\hline
\end{tabular}

Table 5: Total amount of ketorolac among study's groups:

Significant difference was detected between treatment groups in terms of total amount of ketorolac, $\mathrm{p}<0.001$.

\begin{tabular}{|l|c|c|c|c|c|c|}
\hline \multicolumn{1}{|c|}{ Variables } & NL 100 & NL 50 & N IV 0.25 & N IV 0.15 & L & P-value \\
\hline ketorolac amount & & & & & & \\
\hline Mean (SD) & $25(11.3)$ & $30(14.7)$ & $55(14.9)$ & $55(14.9)$ & $57(9)$ & $<0.001$ \\
\hline Median (IQR) & $30(30-30)$ & $30(0-30)$ & $60(60-60)$ & $60(30-60)$ & $60(60-60)$ & \\
\hline
\end{tabular}

Table 6: Onset and Offset of SB among study's groups:

There was significant difference between treatment groups in terms of onset of SB ( $p<0.001)$ and offset of SB $(p<0.001)$.

\begin{tabular}{|c|c|c|c|c|c|c|}
\hline Variables & NL 100 & NL 50 & N IV 0.25 & N IV 0.15 & L & P-value \\
\hline Onset of SB & & & & & & \\
\hline Mean (SD) & $5.1(0.2)$ & $4.9(0.2)$ & $6(0.1)$ & $6(0.1)$ & $6.1(0.1)$ & \\
\hline Median (IQR) & $5(4.9-5.2)$ & $4.9(4.8-5)$ & $6(5.9-6.1)$ & $6(5.9-6.1)$ & $6.1(6-6.1)$ & $<0.001$ \\
\hline Offset of SB & & & & & & \\
\hline Mean (SD) & $25.1(0.7)$ & $26.2(0.2)$ & $18.1(0.3)$ & $20.1(0.3)$ & $17(0.3)$ & $<0.001$ \\
\hline Median (IQR) & $25(24.5-25.7)$ & $26.2(25.9-26.4)$ & $18.1(17.8-18.3)$ & $20.1(19.8-20.3)$ & $17.1(16.8-17.3)$ & \\
\hline
\end{tabular}


Table 7: Onset and Offset of MB among study's groups:

There was significant difference between treatment groups in terms of onset of MB $(p<0.001)$ and offset of SB $(\mathrm{p}<0.001)$.

\begin{tabular}{|c|c|c|c|c|c|c|}
\hline Variables & NL 100 & NL 50 & N IV 0.25 & N IV 0.15 & $\mathbf{L}$ & P-value \\
\hline \multicolumn{7}{|l|}{ Onset of MB } \\
\hline Mean (SD) & $5.1(0.2)$ & $6.1(0.2)$ & $7.8(0.2)$ & $7.6(0.2)$ & $8.6(0.2)$ & \\
\hline Median (IQR) & $5(4.9-5.2)$ & $6.1(5.9-6.2)$ & $7.8(7.6-7.9)$ & $7.6(7.5-7.8)$ & $8.6(8.4-8.6)$ & $<0.001$ \\
\hline \multicolumn{7}{|l|}{ Offset of MB } \\
\hline Mean (SD) & $6.1(0.3)$ & $5.9(0.2)$ & $6.7(0.2)$ & $6.5(0.3)$ & $8.7(0.7)$ & $<0.001$ \\
\hline Median (IQR) & $6.1(5.9-6.2)$ & $5.9(5.8-6)$ & $6.7(6.6-6.9)$ & $6.5(6.2-6.8)$ & $8.9(7.9-9.1)$ & \\
\hline \multicolumn{7}{|c|}{ Onset of tourniquet pain } \\
\hline Mean (SD) & $41(2.1)$ & $43(1.9)$ & $29.1(2.1)$ & $33(2.2)$ & $25.2(2.2)$ & $<0.001$ \\
\hline Median (IQR) & $41(38.9-42.7)$ & $\begin{array}{c}43.1(41.5- \\
44.8)\end{array}$ & $\begin{array}{c}29.2(27.2- \\
30.9)\end{array}$ & $32.9(31-34.8)$ & $\begin{array}{c}25.1(23.2- \\
27.1)\end{array}$ & \\
\hline
\end{tabular}

\section{DISCUSSION}

Since its introduction in the early 1960s, naloxone has emerged as a potent opioid antagonist with fewer side effects than its predecessors. Naloxone hydrochloride is a competitive mu-opioid receptor antagonist for the reversal of opioid overdose in an emergency or inpatient setting. It is approved for administration by a variety of routes, including intravenous (IV) route ${ }^{(5)}$.

In addition, naloxone exerted its effect in dose-dependent manners, in which it demonstrates hypoalgesic and hyperalgesic properties. In high dose (microgram scale), Naloxone antagonize the action of opioid; therefore, the initial recommended dose of 0.8 to $2 \mathrm{mg}$ IV naloxone was determined both by studies in animal models and through use by anesthesiologists to reverse postoperative opioid-induced respiratory depression ${ }^{(\boldsymbol{6})}$.

On the other hand, low doses of naloxone have been found to improve pain control and decrease opioid requirements; most probably through the inhibition of excitatory opioid receptors involved in the tolerance and hyperalgesia often observed with opioid therapy ${ }^{(7)}$. Therefore, a growing body of evidence has proposed the use of adjuvant ultra-low-dose naloxone, along with patient controlled analgesia, to significantly reduce pain intensity, morphine consumption, and opioid-induced nausea and pruritus ${ }^{(8)}$.

However, there is a scarcity in the published literature which assessed the role of ultra-low-dose naloxone in the setting of regional anesthesia. Thus, we performed the present double-blind randomized controlled trials in order to evaluate the effect of adding ultra-low dose of naloxone to lidocaine for IV regional anesthesia among patients undergoing elective short procedures in the upper limb.

The mechanism of the antinociceptive effect of ultra-low dose naloxone is unclear. However, it was reported that low dose naloxone leads to release endorphins, or displaces endorphins from receptor sites. Moreover, naloxone, given as an ultra-lowdose infusion, was proposed to block the negative feedback of large amount of released enkephalins and enhance analgesia from enkephalins ${ }^{(9)}$.

Additionally, the exact mechanism of the reduction in the opioids consumption associated with ultra-low-dose of naloxone is not fully understood. However, it was reported that ultra-low-dose naloxone effects occur by preventing a $G$ protein coupling switch (Gi/o to Gs) of the mu opioid receptor that occurs briefly after acute administration or persistently after chronic administration of opioids. The picomolar binding site for naloxone in these effects is on the scaffolding protein filamin A (FLNA), rather than on opioid receptors. Interestingly, a second, nanomolar binding site on FLNA may disrupt the benefits of binding the picomolar site, perhaps explaining why ultra-low-dose naloxone effects vanish at just slightly higher $\operatorname{doses}^{(\mathbf{1 0})}$.

In the present study, we included 150 patients who were distributed in equal manner to receive one of the following: adjuvant local intravenous naloxone $100 \mathrm{ng} \mathrm{IV}$, adjuvant 
local intravenous naloxone $50 \mathrm{ng} \mathrm{IV}$, naloxone infusion at a rate of $0.25 \mathrm{ug} / \mathrm{kg} / \mathrm{h}$, naloxone infusion at a rate of $0.15 \mathrm{ug} / \mathrm{kg} / \mathrm{h}$, or lidocaine alone. The average age of the included patients ranged from 36 to 39 years old; while almost two-third of the patients were males.

Similar to our findings, Etta and his colleagues ${ }^{(11)}$ performed retrospective study of all patients who underwent upper limb surgeries. The mean age of the included patients was 35 years old; while more than half of the patients were males. Additionally, Madison and his colleagues ${ }^{(12)}$ assessed the efficacy and safety of ultrasound-guided root/trunk (interscalene) block for hand and forearm anesthesia. The author reported that almost $74 \%$ of patients underwent painful unilateral orthopedic surgery of the shoulder at University of California, USA.

Moreover, Rukewe and his colleagues $^{(13)}$ gathered prospective and retrospective data for all the patients who had upper extremity surgeries. The mean age of the included patients, who underwent regional anesthesia, was 39 years old, and the majority of them were males.

In terms of our primary outcomes, patients received local intravenous naloxone 100ng and 50ng had shorter duration of onset of motor and sensory blocks, compared to naloxone infusions and lidocaine groups. Moreover, the patient exhibited longer duration of offset of motor and sensory blocks, compared to patient received IV naloxone infusions and lidocaine groups. The onset of tourniquet pain was significantly delayed in local intravenous naloxone revived patients.

In concordance with these findings, ElSayed and Hasanein (14) conducted a prospective, randomized, double- blind study done at Saad Specialist Hospital, Saudi Arabia; to evaluate the effect of adding ultralow dose of naloxone as an adjuvant to lidocaine for intravenous regional anesthesia. The study included 40 patients undergoing elective short procedures in the upper limb who received either $3 \mathrm{mg} / \mathrm{kg}$ of $2 \%$ lidocaine or naloxone $100 \mathrm{ng}$. The recovery of sensory block was longer in naloxone treated patient compared to lidocaine treated patient. Also the recovery of motor block was significantly longer in naloxone received patient compared to lidocaine alone received patient.
Similarly, in their randomized doubleblind study, Movafegh and his colleagues ${ }^{(7)}$ evaluated the effect of an ultra-low dose of naloxone added to lidocaine and fentanyl mixture on the onset and duration of axillary brachial plexus block. Patients received either $34 \mathrm{~mL}$ lidocaine $1.5 \%$ alone or lidocaine with naloxone 100ng. Both sensory and motor onset times were longer in naloxone group than lidocaine group $(\mathrm{P}<0.001)$. Time to first postoperative pain and motor blockade was longer in naloxone group as well.

The VAS pain is a unidimensional measure of pain intensity, which has been widely used in diverse adult populations. The VAS pain has demonstrated sensitivity to changes in pain assessed hourly for a maximum of 4 hours and weekly for up to 4 weeks following analgesic therapy. Therefore, we used the VAS pain score to assess the change in intraoperative pain during the surgery ${ }^{(15)}$.

Our analysis showed that all naloxone recieved patients show reduction in VAS pain score at the end of surgery $(\mathrm{p}<0.001)$; than patients who received lidocaine alone. In addition, naloxone $100 \mathrm{ng}$ and $50 \mathrm{ng}$ showed less VAS pain score and amount of fentanyl consumption, compared naloxone infusions and lidocaine alone. While, there was no difference between naloxone intravenous infusions and lidocaine alone in terms of VAS pain score and amount of fentanyl consumption.

In concordance with these findings, ElSayed and Hasanein ${ }^{(14)}$ reported greater reduction in intraoperative and postoperative VAS among patients received naloxone, compared to control group. Moreover, intraoperative fentanyl requirement was less in naloxone treated patients and first fentanyl requirement time was significantly longer in naloxone received patients than lidocaine.

Additionally, Ezz and Elkala ${ }^{(17)}$ performed a randomized trial on 60 adult patients scheduled for open globe cataract surgery to evaluate the analgesic effect of ultra-low-dose of naloxone, added to fentanyl and lidocaine for peribulbar anesthesia. The time to first rescue analgesic was longer in naloxone treated patients than control. Moreover, the VAS pain score was significantly lower at 60, $90 \mathrm{~min}, 2$ and $3 \mathrm{~h}$ in naloxone treated patients compared to control. 
Naloxone exhibited a clinically significant efficacy in the setting of spinal anesthesia as well. Sadeghi and his colleagues $^{(18)}$ included 60 patients to receive either $2 \mathrm{~mL}$ saline or IV dose of $100 \mathrm{ng} / \mathrm{kg}$ naloxone after the administration of spinal anesthesia. Total dose of morphine, the VAS pain score at time intervals, and the intraoperative sedation score were significantly lower in the naloxone group.

Moreover, when combined with opioids by a patient controlled analgesia device, naloxone was reported to significantly reduce the opioids consumption as well. Movafegh and his colleagues ${ }^{(7)}$ performed a randomized double-blind study on 90 patients scheduled for total abdominal hysterectomy to investigate the effect of an ultra low dose of naloxone on patient controlled morphine analgesia. Naloxone reduced morphine consumption over the first 24 post-operative hours significantly compared with the controls. The incidence and severity of nausea and vomiting was significantly reduced in the naloxone group.

Similarly, Abolfazl and his colleagues $^{(8)}$ performed a double-blind, randomized, controlled trial on a total of 80 patients scheduled for open discectomy to receive naloxone or placebo after connected to a morphine pump. The authors concluded that infusion of ultra-low-dose naloxone $(0.25$ $\mu \mathrm{g} / \mathrm{kg} / \mathrm{h}$ ) along with morphine PCA can significantly reduce pain intensity, morphine consumption, and opioid-induced nausea and pruritus after lumbar discectomy.

\section{CONCLUSION}

Local intravenous adjuvant naloxone (100 or 50ng) with lidocaine $1 \%$ shortens the onset of blocks and prolongs the recovery from anesthesia. Moreover, it reduces the amount of opioids consumption and intraoperative pain score in patient undergoing short upper limb surgeries. In contrary, naloxone IV infusion not improves the analgesic effect of intravenous anesthesia or prolongs the recovery from anesthesia. Regarding safety, adjuvant naloxone appears to be safe with no recorded side effects.

\section{REFERENCES}

1. Chilvers CR, Kinahan A, Vaghadia H, Merrick PM (1997):
Pharmacoeconomics of intravenous regional anaesthesia vs general anaesthesia for outpatient hand surgery. Can J Anesth., 44(11):11526.

2. Brown EM, McGriff JT, Malinowski RW (1989): Intravenous regional anesthesia: review of 20 years' experience. Can J Anaesth., 36:307-10.

3. Ginsberg B, Glass PS (1997): Opioid-sparing effects of a low-dose infusion of naloxone in patientadministered morphine sulphate. Anesthesiology, 87:1075-81.

4. Tsai RY, Jang FL, Tai YH, Lin SL, Shen CH, Wong CS (2008): Ultralow-dose naloxone restores the antinociceptive effect of morphine and suppresses spinal neuroinflammation in PTX-treated rats. Neuropsychopharmacology, 33:277282.

5. Mowry J, Spyker D, Brooks D, Zimmerman A, Schauben J (2016): 2015 Annual Report of the American Association of Poison Control Centers' National Poison Data System (NPDS). Clin Toxicol., 54:924-1109.

6. Rzasa Lynn R, Galinkin JL (2018): Naloxone dosage for opioid reversal: current evidence and clinical implications. Ther Adv Drug Saf., 9:63-88.

7. Movafegh A, Nouralishahi B, Sadeghi M, Nabavian O (2009): An ultra-low dose of naloxone added to lidocaine or lidocaine-fentanyl mixture prolongs axillary brachial plexus blockade. Anesth Analg., 109:1679-83.

8. Firouzian A, Gholipour Baradari A, Alipour A, Emami Zeydi A, Zamani Kiasari A, Emadi SA et al. (2018): Ultra-low-dose Naloxone as an Adjuvant to Patient Controlled Analgesia (PCA) with Morphine for Postoperative Pain Relief Following Lumber Discectomy: A Double-blind, Randomized, Placebo-controlled Trial. J Neurosurg Anesthesiol., 30:26-31.

9. Sloan P, Hamann S (2006): Ultralow-dose opioid antagonists to 
enhance opioid analgesia. J Opioid Manag., 2:295-304.

10. Burns LH, Wang HY (2010): Ultralow-dose naloxone or naltrexone to improve opioid analgesia: The history, the mystery and a novel approach. Clin Med Insights Ther., 2:857-68.

11. Etta OE, Akpan SG, Eyo CS, Inyang CU (2015): Brachial plexus block for upper limb procedures: experience at the university of uyo teaching hospital, uyo, akwa ibom state, nigeria. $\mathrm{J}$ West African Coll Surg., 5:76-87.

12. Madison SJ, Humsi J, Loland VJ, Suresh PJ, Sandhu NS, Bishop MJ et al. (2013): Ultrasound-guided root/trunk (interscalene) block for hand and forearm anesthesia. Reg Anesth Pain Med., 38:226-32.

13. Rukewe A, Fatiregun A, Alonge TO (2014): Orthopaedic anaesthesia for upper extremity procedures in a Nigerian hospital. Malawi Med J., 26:90-2.
14. El-Sayed W, Hasanein R (2015): A randomized controlled study of the effects of adding ultra-low dose naloxone to lidocaine for intravenous regional anesthesia. Egypt J Anaesth., doi:10.1016/j.egja.2015.09.010.

15. Tashjian RZ, Deloach J, Porucznik CA, Powell AP (2009): Minimal clinically important differences (MCID) and patient acceptable symptomatic state (PASS) for visual analog scales (VAS) measuring pain in patients treated for rotator cuff disease. J Shoulder Elb Surg., 18:92732.

16. Ezz HAA, Elkala RS (2015): Ultralow-dose naloxone added to fentanyl and lidocaine for peribulbar anesthesia: A randomized controlled trial. Egypt J Anaesth., 31:161-5.

17. Sadeghi M, Movafegh A, Nouralishahi B (2008): The Effect of an Intravenous Bolus of Ultra-LowDose Naloxone on Intraoperative Sedation, Post Operative Pain Intensity and Morphine Consumption in Cesarean Section Patients under Spinal Anesthesia. J Biol Sci., 3(1): 15-24. 